http://dx.doi.org/10.5597/lajam00169

\title{
THE TRIUMPH OF THE COMMONS: WORKING TOWARDS THE CONSERVATION of Guiana dolphins (Sotalia guianensis) in the Cananéia estuary, Brazil
}

\author{
Marcos César de Oliveira Santos ${ }^{1, *}$, Marcos Bührer Campolim ${ }^{2}$, \\ Isadora Le Senechal Parada ${ }^{3}$, Patrícia DunKer ${ }^{4}$ and Ednilson da Silva ${ }^{1}$
}

The Ilha do Cardoso State Park (ICSP) is placed in the

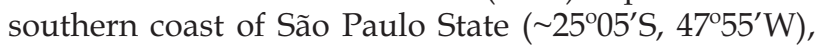
southeastern Brazil. Designated as a protected reserve in 1962, the ICSP has been managed by the Fundação Florestal (FF), a department from the main state environmental agency known as Secretaria do Meio Ambiente (SEMA, 1998; 2001). It is an island of $c a .140 \mathrm{~km}^{2}$ inserted in the Lagamar estuarine complex, which is considered a very important breeding area for many aquatic organisms (Schaeffer-Novelli et al., 1990). Guiana dolphins (Sotalia guianensis) usually approach a beach named Itacuruçá or Pereirinha at the northern border of the ICSP for feeding purposes (see Geise, 1989; Monteiro Filho, 1991; Santos et al., 2000; Santos, 2010). The dolphins' shallow water foraging behavioral displays are unique and make the state park as an interesting spot to observe Guiana dolphins from close distances. Since 1996, a longterm photo-identification study has shown that a few individuals from the whole population use the quoted beach on a regular basis (Santos et al., 2001; Santos, 2004). Moreover, mainly female dolphins named 'beach hunters' use the sloping beach for feeding purposes, showing at least two different strategies to catch their prey (Santos, 2010). As a consequence, it is likely that these unique foraging behaviors displayed by Guiana dolphins represent further proof of cultural transmission in cetacean societies. In the Lagamar estuary, researchers are concerned about losing the opportunity of conducting a longer-term study on beach hunters, which would be important to learn about the way in which the foraging tradition is passed through generations. Whitehead et al. (2004) suggested that in some circumstances and for some species, culture should be integrated into conservation biology. These authors based their suggestion on the definition of culture proposed by Rendell and Whitehead (2001): 'information or behavior - shared by a population or subpopulation - which is acquired from conspecifics through some form of social learning'.

Since the end of the 1990s, tourism activities in the Lagamar estuary have turned into another cause of concern regarding the conservation of the local Guiana dolphin population (see Santos and Rosso, 2007; 2008). It is known that an increase in boat traffic affect dolphin populations worldwide (Janik and Thompson, 1996;
Constantine, 1999; Bejder et al., 1999; Novacek et al., 2001; Lusseau, 2003; Constantine et al., 2004; Lusseau, 2004). Boat traffic increased mainly in the pathway connecting the island of Cananeia, where the main human settlement is found, and the ICSP. One of the main attractions for local tourism is the possibility of observing dolphins at closer distances. Without specific regulations and capacity building programs, injuries to S. guianensis have been reported. For instance, a female Guiana dolphin that usually uses the shallow waters of Itacuruçá beach presented seven parallel marks provoked by the strike with a boat propeller (Figure 1). Also, humans are at risk when trying to touch dolphins on a sloping beach. A swimmer was found drowned in 2006 with injuries after several attempts to interact with dolphins. Therefore, guidelines were urgently needed to conduct dolphin-watching tours as Guiana dolphin calves are seen year-round in the Lagamar estuary and uncontrolled tourism may disrupt important social interactions (Santos and Rosso, 2007; 2008).

In Brazil there are several specific guidelines to reduce the threats to cetaceans at several whale and dolphin watching locations (see Fabris, 1997). However, there are no specific regulations directed towards the observation of $S$. guianensis in almost all its range along the Brazilian coast. Therefore, coastal populations are not only threatened by habitat degradation, incidental captures in fishing operations, pollution and overfishing, but also by the risk of collision with boats, as well as noise pollution by the increasing number of dolphin and whale-watching boats.

Based on the above-described scenario, the aim of this study was to establish guidelines for boat traffic close to Itacuruçá beach at the ICSP. The main objective was to work on the awareness of local people and tourists to act as multipliers of conservation efforts. To reach the proposed objective, a team composed by cetacean researchers, the state park director, a local inhabitant responsible for issuing boat licences through the Brazilian navy, GIS and tourism professionals met together to work on three different targets: (1) establishing a capacity building program to key stakeholders, (2) creating a buffer zone for tourists and dolphins to avoid boat collisions at Itacuruçá beach, and

\footnotetext{
${ }^{1}$ Projeto Atlantis, Laboratório de Biologia da Conservação de Cetáceos, Departamento de Zoologia, Universidade Estadual Paulista 'Júlio de Mesquita Filho', Avenida 24-A, 1.515, Bela Vista, Rio Claro, SP, Brazil, 13506-900

${ }^{2}$ Instituto Florestal/Secretaria do Meio Ambiente do Estado de São Paulo, Estação Ecológica Juréia Itatins, Peruíbe, SP, Brazil

${ }^{3}$ Cota 100 Consultoria Ambiental e Turística, Rua da Quarentenária, 449, Cananéia, SP, Brazil

${ }^{4}$ Associação Rede Cananéia, Rua Antônio Colaço de Soya, 120, Carijó, Cananéia, SP, Brazil

Corresponding author, e-mail: sotalia@gmail.com
} 
(3) working on a specific regulation to protect dolphins and tourists at the same beach. In October 2006, the capacity building program started with several meetings with the following key stakeholders: hotel managers, vessel and small boat pilots, elementary school teachers, environmental police staff, the local community that lives in the ICSP, and the Cananéia association of tour guides, named AMOANCA (Associação de Monitores Ambientais de Cananéia). These meetings usually consisted of short-length lectures on the ICSP regulations, on the unique foraging behaviors displayed by Guiana dolphins at Itacuruçá beach, and about the Brazilian navy basic regulations for safe tours in local estuarine waters. The intention to create a new regulation to boaters and swimmers at Itacuruçá beach was then proposed and stakeholders were asked for feedback. All attendants received an eightpage flyer containing the main information presented on beach hunters and their importance for the local tourism. Flyers were also distributed to hotels to be handed to tourists.

With the help from Brazilian navy officials, a buffer zone placed $200 \mathrm{~m}$ from the mainland and covering a length of around $500 \mathrm{~m}$ was established in the northern border of the ICSP (Figure 2) where boat traffic and fishing are not allowed. Also, tourism boats must leave tourists in a specific area on the beach that is less used by dolphins, and their boats must remain far from the area used by dolphins and tourists. Only local inhabitants can land their boats in the buffer zone to land family members and provisions, and they are the only ones allowed to practice subsistence fishing. Specific buoys approved by the Brazilian navy will indicate the buffer zone area. As of November 2010, the team was still waiting for the Brazilian Navy officials to work on the final details to fix the specific buoys to delimit the buffer zone. Following the recommendations proposed by Tilden (1967), three informative signs containing information on beach hunters, the buffer zone delimitation and the way tourists must behave when dolphins are around were displayed in strategic spots at Itacuruçá beach in vacation months.

As a result from the meetings and feedback from stakeholders, the authors prepared a document to be handled to the main office of the Fundação Florestal (FF), the state organization responsible to manage the ICSP. The document contained a detailed regulation to establish guidelines on the use of Itacuruçá beach by tourism operators, boaters, local community and tourists. The document was handled in December 2006.

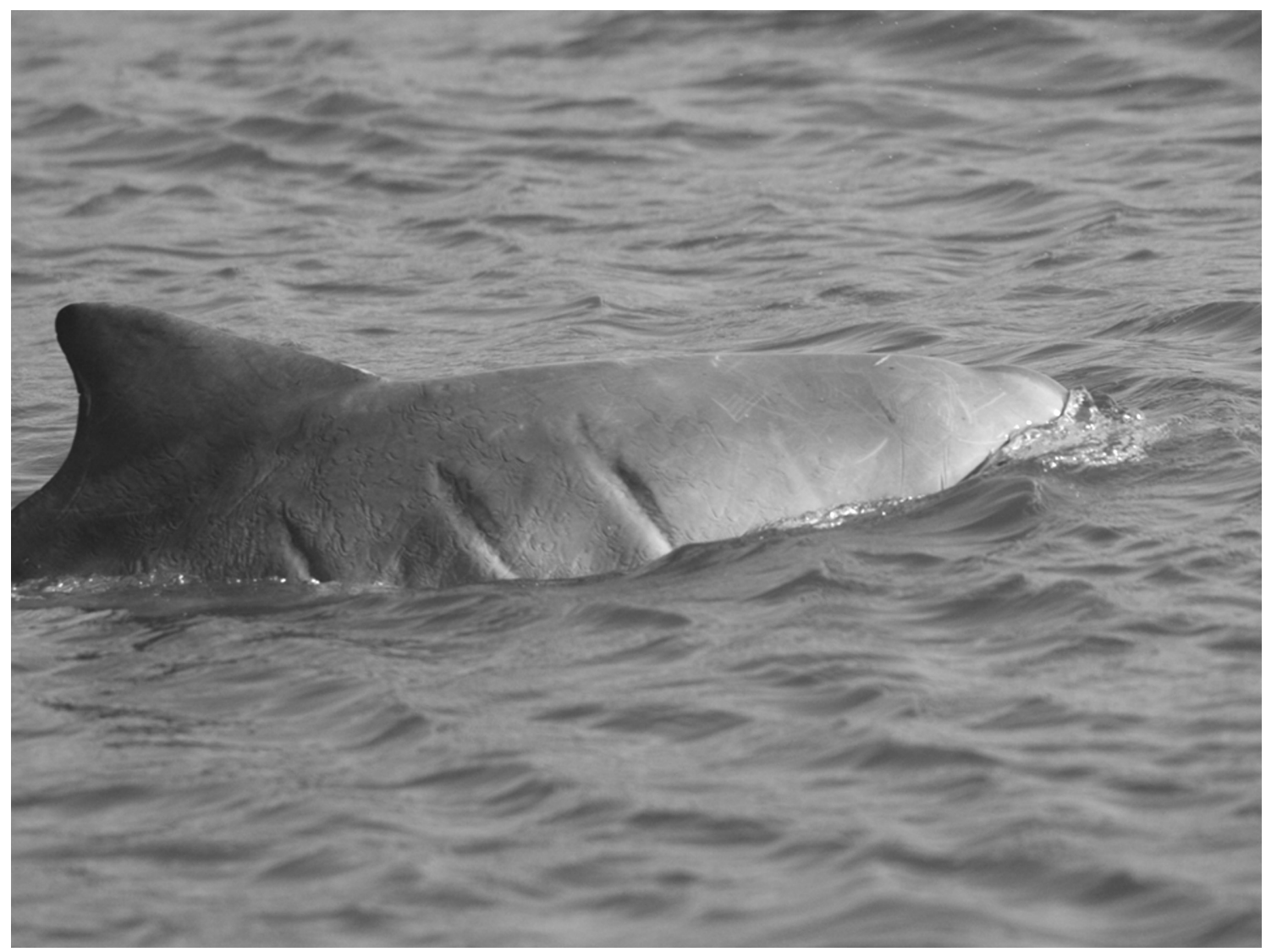

Figure 1. Adult female Guiana dolphin ( $\mathrm{KN} \# 261)$ with propeller marks on its right body side. The increase in tourism operations poses beach hunters in risk of collisions. 


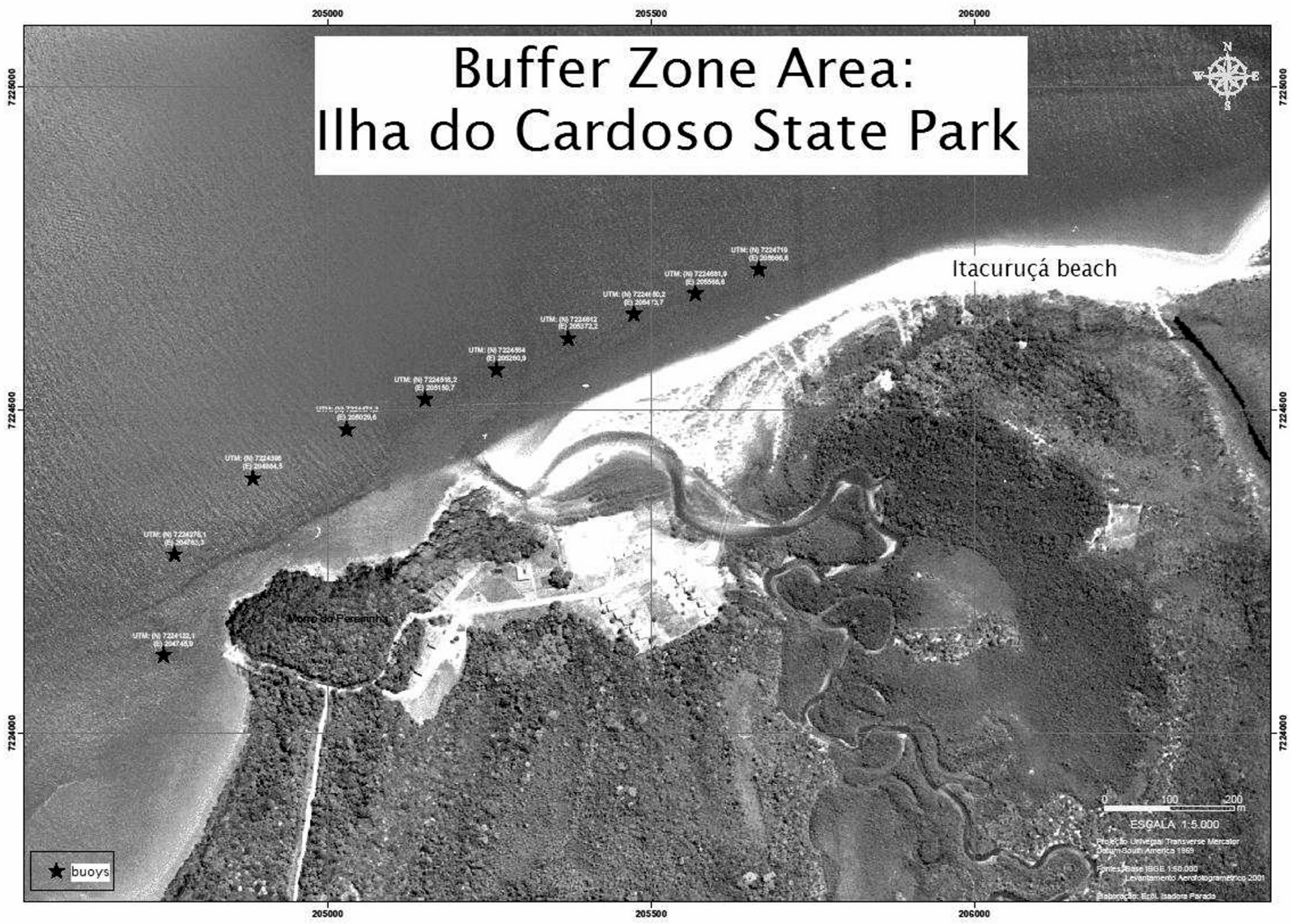

Figure 2. Aerial photograph showing the buffer zone established to protect the northern border of the Ilha do Cardoso State Park. Stars mark locations where buoys will be set.

On 29 September 2007, the guidelines were published by the FF ('Normativa $045 / 2007$ ') and represent an important tool to improve the whole process begun in 2006. As of November 2010, no more accidents regarding swimmers or dolphins were reported, boaters respected the buffer zone even without the fixed buoys, and the quoted beach has been receiving the visits of beach hunters in almost a daily basis. From now on, the next steps will focus on monitoring the consequences of the capacity building program in summer seasons, working on adjustments whenever necessary, and continuing the studies of beach hunters. Only with a long-term survey can a proper evaluation of cultural transmission by beach hunters in the Lagamar estuary can be reached. Meanwhile, it is likely that both tourists and Guiana dolphins can share the benefits arising from a multidisciplinary team effort.

\section{Ackowledgements}

Cetacean Society International, Whale and Dolphin Conservation Society, Earthwatch Institute, CAPES and FAPESP funded the photo-identification studies of $S$. guianensis in the Lagamar estuary. The Earthwatch Institute financially supported the capacity building program conducted in 2006. We thank Vic Cockcroft and an anonymous reviewer for important suggestions to improve the manuscript, as well as to Monica Borobia who managed this manuscript.

\section{References}

Bejder, L., Dawson, S.M. and Harraway, J.A. (1999) Responses by Hector's dolphins to boats and swimmers in Porpoise Bay, New Zealand. Marine Mammal Science 15(3): 738750. http://dx.doi.org/10.1111/j.1748-7692.1999.tb00840.x

Constantine, R. (1999) Effects of tourism on marine mammals in New Zealand. Science for Conservation 106(1):1-60. [Available from Department of Conservation, P.O. Box 10-420, Wellington, New Zealand. <http://www.doc.govt.nz/ upload/documents/science-and-technical/sfc106.pdf >].

Constantine, R., Brunton, D.H. And Dennis T. (2004) Dolphinwatching tour boats change bottlenose dolphin (Tursiops truncatus) behaviour. Biological Conservation 117(3): 299-307. http:/ / dx.doi.org/10.1016/j.biocon.2003.12.009

FABRIS, L.H.F. (1997) Baía dos Golfinhos: Subsídios para o Uso Sustentável dos Recursos Naturais em uma Unidade de Conservação de Uso Direto: Um enfoque participativo. M.Sc. Thesis. Universidade Federal de Santa Catarina, SC, Brazil. 60 pp.

GEISE, L. (1989) Estrutura social, comportamental e populacional de Sotalia sp. (Gray 1886) (Cetacea, Delphinidae) na região estuarino-lagunar de Cananéia, SP e na Baía de Guanabara, RJ. 
M.Sc. Thesis. Universidade de São Paulo, SP, Brazil. 199 pp.

JANIK, V.M. AND THOMPSON, P.M. (1996) Changes in surfacing patterns of bottlenose dolphins in response to boat traffic. Marine Mammal Science 12(4): 597-602. http://dx.doi.org/ 10.1111/j.1748-7692.1996.tb00073.x

LusseAu, D. (2003) The effects of tour boats on the behavior response of bottlenose dolphins: using Markov chains to model anthropogenic impacts. Conservation Biology 17(6): 1785-1793. http:/ / dx.doi.org/10.1111/j.1523-1739.2003.00054.x

Lusseau, D. (2004) The hidden cost of tourism: detecting longterm effects of tourism using behavioral information. Ecology and Society 9(1): 2.

MonTEIRO FiLHo, E.L.A. (1991) Comportamento de caça e repertório sonoro do golfinho Sotalia brasiliensis (Cetacea, Delphinidae) na região de Cananéia, Estado de São Paulo. Ph.D. Thesis. Universidade Estadual de Campinas, SP, Brazil. 99 pp.

NovaceK, S.M., Wells, R.S. AND Solow, A.R. (2001) Short-term effects of boat-traffic on bottlenose dolphins, Tursiops truncatus, in Sarasota Bay. Marine Mammal Science 17(4): 673688. http://dx.doi.org/10.1111/j.1748-7692.2001.tb01292.x

Rendell, L., AND Whitehead, H. (2001) Culture in whales and dolphins. Behavioral and Brain Sciences 24(2): 309-324. http:/ /dx.doi.org/10.1017/S0140525X0100396X

SANTOS, M.C.O. (2004) Uso de área e organização social do bototucuxi marinho, Sotalia fluviatilis (Cetacea, Delphinidae), no estuário de Cananéia, SP. Ph.D. Thesis. Universidade de São Paulo, SP, Brazil. 265 pp.

SANTOS, M.C.O. (2010) Guiana dolphins (Sotalia guianensis) displaying beach hunting behavior in the Cananéia estuary, Brazil: social context and conservation issues. Brazilian Journal of Oceanography 58(2): 143-152. http://dx.doi.org/10.1590/ S1679-87592010000200005

Santos, M.C.O., Rosso, S., Siciliano, S., Zerbini, A.N., Zampirolli, E., Vicente, A.F. And Alvarenga, F. (2000) Behavioral observations of the marine tucuxi dolphin (Sotalia fluviatilis) in São Paulo estuarine waters, Southeastern Brazil. Aquatic Mammals 26(3): 260-267.

Santos, M.C.O., Acuña, L.B. And Rosso, S. (2001) Insights on site fidelity and calving intervals of the marine tucuxi dolphin (Sotalia fluviatilis) in southeastern Brazil. Journal of the Marine Biological Association of the United Kingdom 81(6): 1049-1052. http:/ / dx.doi.org/10.1017/S0025315401005045

Santos, M.C.O. And Rosso, S. (2007) Ecological aspects of marine tucuxi dolphins (Sotalia guianensis) based on group size and composition in the Cananéia estuary, southeastern Brazil. Latin American Journal of Aquatic Mammals 6(1): 71-82. http://dx.doi.org/10.5597/lajam00110

SANTOS, M.C.O. AND Rosso, S. (2008) Social organization of marine tucuxi dolphins, Sotalia guianensis, in the Cananéia estuary, southeastern Brazil. Journal of Mammalogy 89(2): 347355. http:/ / dx.doi.org/10.1644/07-MAMM-A-090R2.1

Schaeffer-Novelli, Y., Mesquita, H.S.L. and Cintrón-Molero, G. (1990) The Cananéia lagoon estuarine system, São Paulo, Brazil. Estuaries 13(2): 193-203. http://dx.doi.org/10.2307/1351589

SEMA (1998) Plano de gestão ambiental - Fase 1 do Parque Estadual da Ilha do Cardoso. Secretaria do Meio Ambiente, Instituto Florestal, São Paulo, v. 108, n. 60. 47 pp. (Available from: Fundação Florestal, Rua do Horto, 931, São Paulo, SP, Brazil, 02377-000).

SEMA (2001) Plano de Manejo do Parque Estadual da Ilha do Cardoso. Secretaria do Meio Ambiente, Instituto Florestal, São Paulo. 196 pp. (Available from: Fundação Florestal, Rua do Horto, 931, São Paulo, SP, Brazil, 02377-000).

Tilden, F. (1967). Interpreting Our Heritage. $2^{\text {nd }}$ Edition, The University of North Carolina Press, Chapel Hill, NC, USA. 120 pp.

WhiteHEad, H., Rendell, L., Osborne, R.W. And WÜRSIG, B. (2004) Culture and conservation of non-humans with reference to whales and dolphins: review and new directions. Biological Conservation 120(3): 431-441. http://dx.doi.org/10.1016/ j.biocon.2004.03.017 